Ying $\mathrm{Xu}^{\star}$ and Evaon C. Wong-Kim

\title{
Moral Resources, Political Capital and the Development of Environmental Protection Organizations in China: A Case Study of City J
}

DOI 10.1515/npf-2015-0006

Abstract: This article combines the moral resources and political capital perspective with the theoretical arguments of guanxi and resource dependence theory to explore the strengths and weaknesses of both the Chinese government-organized and the grassroots environmental protection organizations (ENPOs). Qualitative methods were applied in this study, and the impact of these two entities on environmental protection was also analyzed. The findings mainly include: First, the ascribed political capital can ensure good guanxi with governmental departments, and thus improve an NPO's opportunities to receive resources. Second, although the ascribed political capital enables government-organized ENPOs to run smoothly, their transparency and management need to be improved. Third, though grassroots ENPOs have little of political capital, they possess advantages in terms of the self-chosen moral resource, which can help them become relatively independent from the government and assume responsibility for monitoring the environment. The article concludes with a discussion of implications for policy highlighted by the findings.

Keywords: political capital, moral resources, environmental protection organizations (ENPOs), guanxi, resource dependency theory, China

\section{Introduction}

From an historical perspective, the Chinese government played an almighty role, resulting in social organizations remaining underdeveloped from 1949 through

\footnotetext{
*Corresponding author: Ying Xu, Department of Social Work, The Chinese University of Hong Kong, Hong Kong, China, E-mail: helloyingxu@gmail.com

Evaon C. Wong-Kim, Department of Social Work, California State University, East Bay, Hayward, CA, USA, E-mail: evaon@csueastbay.edu
} 
1970s, and almost all the non-profit organizations (NPOs) suspended from activities until 1978 (Tian 2004), when the Third Plenary Session of the 11th Central Committee of the Chinese Communist Party (CCP) made the decisions to change the focus from that of class struggle to economic construction, and established the principles of emancipating the mind and seeking truth from facts ( $Q u$ 2011). As such, China opted for a state-led incremental approach to political and social reforms, which lead to the appearance of two major categories of NPOs: government-organized NPOs and grassroots NPOs (Xu and Ngai 2011). In the 1990s, state-owned enterprises and institutions gradually abandoned previously supported social service functions, such as healthcare or child care, which created a need for communities to provide social services. Thus, the Chinese government cautiously welcomed the social welfare role played by NPOs (Xu 2012a). As a result, while the vast majority of NPOs were set up by the government, some grassroots NPOs, which primarily provide voluntary services, have emerged (Tian 2004; Xu and Ngai 2011).

Of the various NPOs that have been formed, environmental NPOs (ENPOs) have a primary goal of protecting the environment, which provides certain advantages because the central government has expressed support for environmental protection since the 1970s. For example, as early as 1972, China participated in the global environmental arena by attending the United Nations Conference on the Human Environment in Stockholm. In 1973, China held its first National Environmental Protection Conference in Beijing and created its own environmental protection agency at both the central and local levels (Ma and Ortolano 2000; Ru and Ortolano 2009).

Nevertheless, in line with the market-oriented reform, the social belief that "development is an absolute principle" is widely accepted by the Chinese society, and "treatment after pollution" is sometimes tolerated by local governments (Gilley 2012). Environmental policies issued by the central government were regarded as a drag on gross domestic product (GDP) growth and "a weight around the neck of local development plans" (Chandler and Wang 2009, 4). Consequently, as with many rapidly developing countries, China's pollution levels are rising. ${ }^{1}$ In 2005, the Chinese government reported over 87,000 cases of social unrest, where concerned citizens were demanding their right to a clean environment (Pacific Environment 2009). In addition, 76.4\% of the public believed that China's current environmental problems were "very serious" and

1 In 2007, China was home to 16 of the 20 most polluted cities in the world, as listed by the World Bank (Pacific Environment 2009). 
"relatively serious" and caused crisis to public health (China Environmental Culture Promotion Association 2008, 2).

Thus, in contrast to some other social organizations, the Chinese central government and the masses prefer to support the ENPOs because they believe that the organizations are pursuing public good rather than self-interests $(\mathrm{Ru}$ and Ortolano 2009; Xu and Ngai 2011; Xu 2013). As a result, both the government-organized ENPOs and the grassroots ENPOs have developed since the mid1990s. For example, in 1994, there were only nine ENPOs (including four student environmental organizations) in mainland China (Yang 2005). And in 2008, the number of ENPOs was greater than 3,500, including 1,309 government-organized ENPOs, 1,382 student-environmental organizations, 508 grassroots ENPOs, 90 branches of international environmental organizations in China, and 250 ENPOs from Hong Kong, Macao, and Taiwan (People 2008). However, since China is in a period of rapid transition and since environmental protests are on the rise, the development of ENPOs with different backgrounds has been uneven. For example, the government usually supports the "trustable" ENPOs that have certain governmental backgrounds (e.g., NPOs set up by retired officials) and views grassroots ENPOs with skepticism (Qi 2004; Cooper 2006, Chen 2007; Lang and Xu 2013).

To better understand the challenges faced by government-organized and grassroots ENPOs in China, this study combines the moral resources and political capital perspective with the theoretical arguments of guanxi and resource dependence theory to compare two typical ENPOs established at about the same time in the same city: one organized by the government (ENPO-1) and the other grassroots (ENPO-2) (Bian and Ang 1997; Froelich 1999; Gao and Acar 2005; $\mathrm{Xu}$ and Ngai 2011; Chen, Chen, and Huang 2013).

The following sections of this article are organized into eight sections. Section 1 begins with a literature review of the current regulations and governance of NPOs in China. Section 2 next reviews resource dependence theory, the concept of guanxi, and the theoretical perspectives of moral resources and political capital in the Chinese context. Section 3 follows by describing the research method, after which Sections 4-6 report the findings of our analysis. Section 7 discusses the findings and implications for policy, after which Section 8 concludes the article by identifying the contributions and limitations of the study.

\section{Regulations and Governance of NPOS}

There is currently no national law regulating NPOs in China; however, the State Council has issued three regulations that should be regulated by the Ministry of 
Civil Affairs: (1) Regulations on the Registration and Administration of Social Organizations (State Council 1998a) (Shehui tuanti dengji guanli tiaoli), (2) Regulations on the Registration and Administration of Private Non-enterprise Units (State Council 1998b) (Minban feiqiye danwei dengji guanli tiaoli), and (3) Regulations on the Registration and Administration of Foundations (State Council 2004) (Jijinhui guanli tiaoli). According to these regulations, NPOs are required to be registered in one of the following three categories: (1) the "social organizations" that are officially defined as "non-profit organizations which are formed voluntarily by Chinese citizens in order to realize the shared objectives of their members and which carry out activities according to their charters"; (2) "private non-enterprise units" that are officially defined as "non-profit social organizations which are using non-state assets and formed by enterprise or course units (qiye shiye danwei), social organizations, and other social forces or citizens"; and (3) "foundations" that are officially defined as "non-profit juristic persons who utilize the assets denoted by natural person, juristic person, or other organizations to improve the commonwealth."

Since it requires a primitive fund of no less than RMB $¥ 4$ million to establish a "public-raising foundation" that can collect donations from society, or RMB¥2 million to establish a "non-public foundation" that cannot raise money from the public, most NPOs that do not have enough money seek to register as "social organizations" or "private non-enterprise units." Current regulations create more requirements and are granted more autonomy for the former than the latter. For instance, registering as a "social organization" requires at least 50 individual members or 30 institutional members. Additionally, national-level organizations must have a minimum of RMB $¥ 100,000$ to cover their activities, while local social organizations and inter-area social organizations must have a minimum of RMB¥30,000. In contrast, "private non-enterprise units" have no requirements regarding number of members and amount of funds. Thus, the organizations which cannot register as social organizations choose to register as private no-enterprise units instead (State Council 1998a, 1998b).

One of the similarities between social organizations and private non-enterprise units is that they both need the professional management unit to get registered because both of them can make a profit. As explained by the Ministry of Civil Affairs, social organizations and private non-enterprise units don't always have to be non-profit: the biggest different between social organizations as non-profit organizations and companies and enterprises that are profitable is not whether they can profit or not, but how they distribute the profits they earn. The reason for this is that "unlike government organs and fullfunding institutions, social associations, if only counting on the membership dues, donations and government support, would get far less funds. The income 
from developing economic entities, holding activities and providing services within the approved business scope are the major funding channels of supplementation. And the purpose of this is to make the organizations develop more healthily" (Ministry of Civil Affairs 2002). Meanwhile, social organizations and private non-enterprise units can adopt the same tax rate (State Administration of Taxation 1999).

Alternatively, there are many differences between social organizations and private non-enterprise units. First, social organizations can set up private nonenterprise units, but private non-enterprise units cannot set up social organizations. Second, social organizations can set branches with permission, while private non-enterprise units cannot set any branches. Third, social organizations are "membership organizations" that can collect member fees, while private non-enterprise units are not allowed to collect member fees.

Despite their differences, certain rules apply to both social organizations and private non-enterprise units. For example, any social organizations or private non-enterprise units must be approved by and registered with the Civil Affairs departments at the county level or above, and the foundations must be approved at the provincial or central government level. Furthermore, before applying for registration at a certain level of the Ministry of Civil Affairs, the social organization, the private non-enterprise unit, and the foundations are also required to find a "professional management unit" (yewu zhuguan danwei), which is a state organ above the county level that is relevant to NPO activities.

Moreover, current regulations restrict the number, types, and range of NPOs: if an NPO has already been registered in one administrative area, that area is considered off-limits to other NPOs of the same type. For example, if an association of environment protection already exists at the city level in Beijing, then Beijing will not approve the registration of a similar association ( $\mathrm{Xu} 2012 \mathrm{~b}$ ).

In reality, not many government agencies are willing to act as their professional management unit, as they have to conduct the annual review (niandu jiancha) and play a supervisory role to the NPOs, which will add to their workload. As a result, there are millions of unregistered NPOs because the regulations on the registration and governance of NPOs are too strict. Wang and Jia (2003) estimated that the number of unregistered organizations is about 10 times that of registered ones.

It is worth noting that unregistered NPOs are not necessarily banned by the government since the government is willing to give a larger role to the voluntary sector, registered or otherwise. Under certain circumstances, some unregistered NPOs can be very active (Qi 2004). For example, a well-known ENPO, Green Earth volunteers (Lüjiayuan), conducted environmental protection work all over China but was never registered. Moreover, Green Earth volunteers has been 
awarded several national prizes in the field of environmental protection (Qi 2004; Xu 2012a). Notably, Green Earth volunteers was established by a senior journalist in Beijing, where he could seek support from either individual elites and/or various professional organizations. In most inland areas of China, where the social and political environments are relatively conservative, unregistered NPOs are more likely to experience difficulties than the registered ones.

In actuality, scholars have noted that as long as the current official rules upon NPOs remain strict and give government officials the legal right to interfere with or control the NPOs' activities, the NPOs that cannot win the trust of the government may have a hard time when seeking official registration, receiving external fund, and/or launching their projects publicly (Cooper 2006; Cai 2010). For example, on July 17, 2009, Chinese officials shut down Gongmeng (i.e., Open Constitution Initiative), a legal aid and research centre founded by pioneering Chinese lawyers, who have been involved in many high-profile cases, such as representing parents whose children were became ill due to milk tainted with melamine (The Economist 2009).

\section{Rethinking the Relationship between NPOS and the Chinese Government: Resource Dependence, "Guanxi", and the Moral Resources and Political Capital}

Since NPOs need resources to support their operations, scholars have developed and applied resource dependence theory to examine these organizations' development, often in terms of their within- and cross-sector collaborations (Pfeffer and Salancik 1978; Froelich 1999; Eikenberry and Klover 2004; Gao and Acar 2005; Macedo and Pinho 2006). And it was found that NPOs' forms of collaboration and resource dependence were affected by their institutional environment, structural contexts, and a handful of organizational process factors (Galaskiewicz 1985; Oliver 1990; Baum and Dutton 1996; Young, Bania, and Bailey 1996; Young 1998; Cigler 1999).

In China, private contributions to ENPOs remain stunted because private Chinese citizens are generally unwilling to donate due to dismal public trust in Chinese NPOs (Xu 2012a); ${ }^{2}$ thus the funding opportunities for Chinese NPO

2 Chinese NPOs' internal governance has been characterized by irregularity, a lack of transparency, and a kind of disrepute, all of which Guo Meimei's scandal only exacerbated. In 2011, 20-year-old Guo fraudulently alleged on Sina Weibo that she was the general manager of the 
significantly depend on whether the organization can foster and maintain a good relationship with the government. Moreover, as it is believed that Chinese culture usually has a tradition of emphasizing a "relationship-based" social relationship network such as kinships or family ties (Fei, Hamilton, and Wang 1992), scholars have applied the Chinese term guanxi, defined as "relational entities and their relationships," to investigate how NPOs develop relationships with the government (Bian and Ang 1997; Lu 2009; Chen, Chen, and Huang 2013). Yet, given case-based differences regarding views on guanxi, it remains unclear what kind of guanxi can best enhance an NPO's ability to acquire resources from the Chinese government (Ma 2002; Lu 2007, 2009). For example, in this study, though ENPO-2 has developed relatively good guanxi with the Department of Civil Affairs, the organization continually has to negotiate the difficult guanxi maintained with its professional management unit, the Environmental Protection Department.

In other words, good guanxi with a certain governmental department or representative does not necessarily prompt profound resources for an ENPO. Yet, because the forms of resource dependence exhibited by Chinese NPOs are more complex than current perspectives on guanxi accommodate, new perspectives on the development of NPOs in China are necessary. In this article, we therefore combine perspectives on moral resources and political capital with the theoretical arguments of guanxi and resource dependence theory to explore Chinese ENPOs' strengths and weaknesses in promoting environmental protection.

Among various conceptual lenses, the perspective focusing on moral resources and political capital is a newer theoretical model for the organizational level that reflects efforts to understand the unique interactions between the government and NPOs in China (Xu and Ngai 2011). The term moral resources has been defined as the existing morals or ethics that could be adopted by any organization. Despite no universal understanding of the concept of morals, two types of moral resources have been proposed: self-chosen moral resource-I and societally recognized moral resource-II. On the one hand, self-chosen moral resource-I refers to self-chosen moral resources, including ethical beliefs, which enhance an NPO's level of confidence and in turn enables it to overcome difficulties in defining its mission and activities. On the other, societally recognized moral resource-II is a socially recognized moral resource,

Red Cross Society of China, a claim that she juxtaposed with boasts of her luxurious lifestyle and images of her Maserati and Lamborghini, expensive handbags, and palatial villa (China Digital Times 2013). Though later shown to be an imposter, Guo scandalized the Chinese public, which expressed widespread skepticism of how the NPOs were using private donations. Shortly after, private donations to the NPOs plunged. 
meaning that its ethics are received well by the respective society. If the moral principles espoused by an NPO are socially accepted, then it can win the trust and support of the public, and as a result, the government may facilitate its development (ibid).

Generally, any organization can choose its moral resource from all available morals and according to its mission. Yet, not all organizations can process the societal-recognized moral resource-II because not all values are recognized by certain governments or societies (Kant 1998; Adorno 2000; Xu and Ngai 2011). For example, ENPOs are more likely to gain the trust and support of people and the government if both latter entities believe that the ENPOs are concerned with the long-term benefit of society. In this case, an ENPO's self-chosen moral resource-I of environmental protection is also the organization's societal-recognized moral resource-II, which is helpful in cultivating the government's trust. At the same time, environmentalism may not be accepted well by a certain locale when the local government and people are eager to achieve economic development and believe that "treatment after pollution" is acceptable ( $\mathrm{Ru}$ and Ortolano 2009). In this case, although environmentalism cannot serve as the societalrecognized moral resource-II, the environmental beliefs may boost the confidence of ENPO members in the organization's services, thereby helping the ENPO to overcome any difficulties in defining its mission and activities.

Political capital refers to capital that can enhance an individual's or organization's status, possessions, or access to the current political system (Xu and Ngai 2011). There are two types of political capital: ascribed political capital-I, which refers to the political status that is conferred upon certain organizations through historical inheritance, and achieved political capital-II, which refers to political resources achieved by the organization's own efforts (Bourdieu 1998; $\mathrm{Xu}$ and Ngai 2011).

In China, for instance, political capital can determine an organization's legal status and aid in the organization's development. In fact, certain organizations can even dispense with registering by possessing ascribed political capital-I. For example, article 13 of the Regulations on the Registration and Administration of Social Organizations (State Council 1998a) includes three exceptions to the rule of registering: (1) organizations that have sent representatives to attend the National Committee of the Chinese People's Political Consultative Conference, (2) organizations authorized by the department of management for the establishment of organizations of the State Council and approved by the State Council of registering free; (3) internal organizations approved by government organs, institutions, enterprises, and institutions that are active internally.

These organizations are invariably government-organized non-governmental organizations (e.g, the Chinese Communist Youth League and the All-China 
Women's Federation) with profound ascribed political capital I and privileged positions in China's one-party system (Xu 2012b; Xu forthcoming). Most often, these GONGOs not only enjoy exemptions of registration, but also can act as the professional management unit for NPOs and sometimes even issue new regulations to supervise NPOs (Xu 2012b).

However, in a relatively conservative political environment, though political capital may heavily sway resource allocation, moral resources are nevertheless valuable possessions that grassroots organizations should treasure. $\mathrm{Xu}$ and Ngai's (2011) previous research has shown that while most grassroots NPOs have little ascribed political capital-I, it is likely that they may achieve political capital-II by conducting their regular services if the government considers such services to be morally right.

\section{Method}

I became aware of the uniqueness of ENPO-1 and ENPO-2 in 2006, when I was conducting a wider study that aimed to explore the development of civil society in City J of China. Since then, I have collected documentary data related to the development of ENPOs, including official documents, internal publications, meeting notes, newspaper articles, and articles on Bulletin Boards (BBS). Moreover, I regularly visited City J to observe the ENPOs' operation and met with board members or key volunteers to update my knowledge of the latest development of ENPOs between 2006 and 2015.

\subsection{The Research Site}

The study was conducted in City J, which is a Chinese "Middletown" (Lynd and Lynd 1929) that is considered to be more representative of Chinese cities than metropolises, such as Beijing or Shanghai, in terms of economic development, population density, and the NPOs' history. City J is an inland city with an overall competitiveness in the range of 22 and 26 among the 200 cities in China (Ni 2006; China Institute of City Competitiveness 2011). According to the Sixth National Population Census in 2010, 6,814,000 people live in the city (Statistical Information Net of City J 2015). Moreover, City J is the first city of Province S in which the municipal government tries to regulate NPOs' activities and issued the Regulations on Voluntary Service in 2006 (The gateway website of the City J People Government 2006). 
In addition, City $\mathrm{J}$ is considered to be one of China's "National Heritage Cities," with a rich cultural heritage and history that reflects almost every important social and cultural change in China (Lin 2004). It has been the capital city of Province S since the Ming dynasty, and has been a center of politics, culture, education, science and technology, and economy of the Province.

Moreover, City J has a tradition of charitable organizations. By 1935, the "female moral agency" had absorbed up to 1,717 female members in City J, which is more members than in big cities such as Shanghai and Beijing (Zhao 2005). However, the NPOs' development was interrupted because of the SinoJapanese War, the civil war, and other political movements since 1938. Thanks to economic and social reforms, the NPOs have re-emerged in the city with the government's encouragement since the 1990s.

\subsection{Sampling, Data Collection, and Data Analyses}

As illustrated above, the government-organized ENPOs exist simultaneously with the grassroots ENPOs in China. Meanwhile, because current regulations restrict the number, types, and ranges of NPOs, there is only one "provinciallevel" environment protection foundation (i.e., ENPO-1) and one "city-level" social organization (i.e., ENPO-2) in City J. Therefore, ENPO-1 and ENPO-2 were selected by the purposive sampling: ENPO-1 is a typical government-organized ENPO. The organization's former president had served as the vice governor of Province S, and the current president is the former deputy director of the environmental protection bureau. ENPO-2 is a grassroots ENPO that has little connection with the government (Interview, Officer A, December 28, 2006; II-Volunteer5, December 23, 2006; I\&II-Volunteer7, February 10, 2007).

Then, by using the purposive sampling and snowball sampling methods, as Table 1 illustrated, 12 key informants were interviewed. Firstly, through the purposive sampling, two organizers and three officials were selected: Organizer-1 was only person who was responsible for organizing and carrying out the activities of ENPO-1; Organizer-2 was the founder and the only full-time staff member of ENPO-2; and the three officials were directly responsible for governing the social organizations in City J. Secondly, by using snowball sampling, three volunteers of ENPO-1, who have served in ENPO-1 for at least one year (i.e., I-Volunteer1, I-Volunteer2, I-Volunteer3); three volunteers of ENPO-2, who have served in ENPO-2 for at least one year (i.e., II-Volunteer4, IIVolunteer5, II-Volunteer6); and one volunteer who served for both ENPO-1 and ENPO-2 (i.e., I\&II-Volunteer7) were selected. 
Table 1: List of interviewees.

\begin{tabular}{|c|c|c|}
\hline & Code number & $\begin{array}{l}\text { Sampling } \\
\text { method }\end{array}$ \\
\hline The organizer of ENPO-1 & Organizer-1 & $\begin{array}{l}\text { Purposive } \\
\text { sampling }\end{array}$ \\
\hline The organizer of ENPO-2 & Organizer-2 & $\begin{array}{l}\text { Purposive } \\
\text { sampling }\end{array}$ \\
\hline The three officials & $\begin{array}{l}\text { Officer- } A \text {, Officer-B, and } \\
\text { Officer- } C\end{array}$ & $\begin{array}{l}\text { Purposive } \\
\text { sampling }\end{array}$ \\
\hline Three volunteers of ENPO-1 & $\begin{array}{l}\text { I-Volunteer1, I-Volunteer2, } \\
\text { I-Volunteer3 }\end{array}$ & $\begin{array}{l}\text { Snowball } \\
\text { sampling }\end{array}$ \\
\hline Three volunteers of ENPO-2 & $\begin{array}{l}\text { II-Volunteer4, II-Volunteer5, } \\
\text { II-Volunteer6 }\end{array}$ & $\begin{array}{l}\text { Snowball } \\
\text { sampling }\end{array}$ \\
\hline $\begin{array}{l}\text { A volunteer served for both } \\
\text { ENPO-1 and ENPO-2 }\end{array}$ & I\&II-Volunteer7 & $\begin{array}{l}\text { Snowball } \\
\text { sampling }\end{array}$ \\
\hline
\end{tabular}

Semi-structured, in-depth face-to-face interviews were conducted in December 2006, February 2007, July 2012, and December 2013. Each participant was interviewed one to four times. Moreover, to clarify and deepen the understanding of the interview data and to attain a better understanding of the recent development of the ENPOs, communication between the first author and the interviewees via phone or email continued intermittently until November 2014.

The interview data were transcribed verbatim and all interviewees signed a consent form, declaring their understanding that the interviews would be recorded. Code numbers, rather than names of organizations and informants, were applied to ensure anonymity. Additionally, the qualitative data analysis software Nvivo 9.0 was used to assist with data analysis.

\section{Political Capital and Government's Supports}

\subsection{The Government-Organized ENPO-1: Ascribed Political Capital-I Helps in Getting Government's Supports and Resources}

In the late 1990s and early 2000s, the Chinese government underwent extensive administrative reforms. Government-organized ENPOs had been created at both national and provincial levels (Wu 2003). As illustrated above, ENPO-1 is such a government-created organization that both the ex-president and the current 
president are retired provincial-level governors. With the backing of the government, the cadres and government officials from various departments at various levels strongly support all the activities organized by ENPO-1 (Documentary data, Major Events of ENPO-1, 2003-2013). Thus, ENPO-1 has undoubtedly occupied a certain ascribed political capital-I, which enables its activities to run smoothly.

Evidence showed that ENPO-1 gets copious amounts of direct support from the government. For example, when ENPO-1 was registered at the Department of Civil Affairs of Province S in 2001, Qu Geping, the member of the Standing Committee of National People's Congress and the director of the Environment and Resources Council of China, attended and made a speech at the inaugural meeting. In addition, the vice governor of Province $S$ and the deputy director of the People's Congress of Province S, also attended the meeting to celebrate ENPO-1's establishment (Documentary data, Yearbook 2002 of Province S).

Moreover, 24 out of 25 documented environmental protection activities between 2005 and 2013 were large-scale events that required ENPO-1 to cooperate with eight universities, three technical secondary schools, seven primary schools, and related government departments such as the River Bureau of Province S, the Environmental Protection Bureaus of Province S and City J, and so on (Documentary data, Major Events of ENPO-1, 2003-2013). ${ }^{3}$ Numerous senior and middle-ranking leading cadres representing the following government departments joined the environmental propaganda/education activities organized by ENPO-1: Province S's People's Congress, the Environmental Protection Agency of Province S, Department of Land and Resources of Province S, Propaganda Department of the Provincial Party Committee, the Environment Committee of the provincial People's Congress, Human Resources and Environmental Committee of the provincial Chinese People's Political Consultative Conference, the Municipal Commission of the Urban Environment of the People's Congress of City J, the Public Security Bureau of City J, and the Environmental Protection Agency of City J) (Documentary data, Important Events of ENPO-1).

In addition, thanks to the government's support, ENPO-1's environmental protection activities easily attract media attention. This is not only because of the presence of government leaders but also the large number of activities and the support of the collective members. This helped ENPO-1 gain positive public exposure and is very helpful for getting tangible and intangible resources, such as donations from benevolent corporations and building a positive image of

3 Among the 25 activities, one activity was primarily coordinated with a big company (i.e., Amway) in 2013. This activity aimed to raise the children and youth's awareness of environmental protection through family activities. 
being environmentally friendly through mass media (Interviews: Organizer-1, December 18, 2006; I-Mr. Wang, January 4, 2007). In turn, the positive image will help ENPO-1 gain more support from the government. In other words, the ascribed political capital-I can help ENPO-1 obtain more political capital, which is the achieved political capital-II, as termed by Xu and Ngai (2011).

Thanks to the societal-recognized moral resources-II and the ascribed political capital-I, ENPO-1 has enough "human resources" as it can recruit a large number of volunteers to support its activities. Actually, in 2006, there were only three fulltime staff members working in ENPO-1 (i.e., the president, the general secretary, and organizer-1) (Interview, Organizer-1, December 18, 2006). In 2015, though ENPO-1 wishes to recruit several new staff, the total number of the staff still remains less than 20 (Documentary data, Recruitment Advisement of ENPO-1). Therefore, in order to conduct large-scale "propaganda actions," ENPO-1 always recruits lots of volunteers. As a volunteer, I\&II-Volunteer7, explained, "Some volunteers join voluntarily because they wish to help protect the environment; others join compulsorily. For example, their schools or institutions (danwei) ask them to support ENPO-1's activities" (February 10, 2007).

\subsection{Grassroots ENPO-2: Lacking Political Capital and Getting Little Support from the Government}

The background of ENPO-2 is quite different from ENPO-1, which benefits from ascribed political capital-I. The founder of ENPO-2, Organizer-2, is a businessman and amateur photographer, who likes to shoot natural and environmental themes. Lacking the ascribed political capital-I, ENPO-2 has to overcome many difficulties that ENPO-1 never encountered.

Unlike ENPO-1, when multiple leaders celebrated its establishment, ENPO-2 must work hard to seek legal status. In 1998, Organizer-2 left his business and committed himself to setting up ENPO. Endeavoring to advance environmental protection in a formal and professional way, Organizer-2 hoped ENPO-2 could be formally registered as a "social organization" (Interviews, Organizer-2, December 20, 2006, and July 24, 2012; II-Volunteer5, December 23, 2006; I\&II-Volunteer7, December 31, 2006). However, the application process took four years because no government organ wished to be its professional management unit. Finally, in 2002, the Environmental Protection Bureau of City J agreed to be its professional management unit, and ENPO-2 was finally registered as a "social organization" at the Department of Civil Affairs of City J (Interview: II-Volunteer5, December 23, 2006). 
According to II-Volunteer6, who is one of the key volunteers and also a friend of Organizer-2, although Organizer-2 knew several government officials in City J when he was a businessman, the relationship with the government was too weak to allow a department to take on additional work and responsibilities to supervise a grassroots ENPO. However, in the 2000s, almost every city had set up an ENPO, and City J, as the capital city of Province S, should also have an ENPO. Thus, several deputies of the People's Congress of City J helped Organizer-2 persuade the leaders of the Municipal Environmental Protection Bureau to accept ENPO-2's application. Organizer-2's perseverance and hard work finally paid off as, according to II-Volunteer6, "Organizer-2 walked his legs off and talked himself hoarse during the 4-year-long application" (Interview, December 20, 2006).

Additionally, even though the Environmental Protection Bureau of City J agreed to be ENPO-2's professional management unit, the leaders were reluctant to support ENPO-2 and asked Organizer-2 to find another governmental department to be its professional management unit every year when ENPO-2 needed an annual review. Organizer-2 described the situation as follows:

The Environmental Protection Department, our professional management unit, would not like to take the responsibility of supervising us and keeps on suggesting we find another one, for example, the Municipal Committee of the Communist Youth League (CYL). I have made an application to the CYL, and the CYL agreed. However, according to the regulations of social organizations, the Department of Civil Affairs cannot approve this since CYL's main work does not relate to environmental protection. Moreover, each year, we have difficulties in passing the annual review, since our professional management unit does not want to take that responsibility and would like to block us. (Interview, December 16, 2006)

Similarly, an officer of the Department of Civil Affairs of City J, Officer-A, told the following story of the poor relationship between the Environmental Protection Department of City J and ENPO-2:

Any NPO that wishes to change their registered address requires its professional management unit's approval by affixing a seal on a form. When ENPO-2 wanted to change its address, the Environmental Protection Department of City J would not affix the seal. Our colleagues (working in the Department of Civil Affairs of City J) made efforts to reconcile the disputes and, finally, ENPO-2 got its seal... Actually, when ENPO-2 was founded, we also helped ENPO-2 to get the approval from the Environmental Protection Department. (Interview, December 28, 2006)

Moreover, in the latest interview, about five years after the first interview, Organizer-2 expressed that the poor guanxi between ENPO-2 and its professional management unit has never changed. Moreover, he observed the following when 
describing how his organization (ENPO-2) is different from ENPO-1 in terms of political capital:

The Environmental Protection Department, our professional management unit, regards us as an extra burden. They intend to block us, and every time they do not wish us to pass the annual review.... This year, they haven't returned the review documents to us by now. We cannot organize any activities until they return the documents to us. In other words, our activities should be regarded as illegal without the approval documents.... ENPO-1 is organized by the government and they can easily get the support from the government. Yet, as a grassroots NPO, we have realized that we should not expect to get support from the government as easily as ENPO-1 did. (July 24, 2012)

\section{Moral Resources and Environmental Protection Activities}

\subsection{The Government-Organized ENPO-1: To Improve Environmental Awareness}

In 2002, Jiang Zemin, who was the General Secretary the CCP Central Committee, expressed his thoughts about environmental protection in his report at the 16th National Congress of the CCP, "We will enhance harmony between man and nature to push the whole society onto a path to civilized development featuring the growth of production, an affluent life, and a sound ecosystem" (Xinhuanet 2002). As a government-organized ENPO, ENPO-2 clearly states on its official website that the organization is willing to "carry out environmental education, to improve environmental awareness, and to act in the spirit of the 16th National Congress of the CCP" (Documentary data, Introduction of ENPO-1, 2014). In this regard, ENPO-1's self-chosen moral resource-I includes a two-fold objective: to improve environmental protection and to assist in the implementation of the CCP's spirit.

According to Xu and Ngai (2011), an organization's self-chosen moral resource-I can be equal to moral resource-II if the organization's moral resource-I is also socially supported. With little doubt, ENPO-1's above statements are also easily supported by the government and society. In this regard, ENPO-1's moral resource-I can also be regarded as ENPO-1's societal-recognized moral resources-II.

In line with its self-chosen moral resource-I, ENPO-1's activities focus on the environmental propaganda and education that mainly targeted youth and children (Documentary data, Major Events of ENPO-1, 2003-2013). For example, 
24 out of the 25 activities that ENPO-1 conducted during 2005-2013 are categorized as "propaganda actions," and 19 out of the 25 aimed to educate children and youth through the propaganda.

\subsection{The Grassroots ENPO-2: Promote the Ideal of Preserving Nature and Advancing Environmental Monitoring}

According to ENPO-2's website, its mission is "to promote the idea of preserving nature, living in Harmony with Nature, and to enhance communications between people and the government." Also mentioned is ENPO-2's aim to gradually establish the mechanism of public participation in environmental monitoring and protection (Documentary data, The Profile of ENPO-2, 2007).

According to the above information, we may find that, as an environmental protection organization that is similar to ENPO-1, ENPO-2 also adopted the ideal of environmental protection as its self-chosen moral resource-I and societalrecognized moral resources-II. Conversely, unlike ENPO-1's primary focus on promoting environmental propaganda, ENPO-2 aims "to enhance communications between people and the government" and "to establish the mechanism of public participation in environmental monitoring and protection." In this sense, in addition to the ideal of being environmentally friendly, ENPO-2's self-chosen moral resource-I includes independent civic values, such as public participation in environmental monitoring. However, the ideal of environmental monitoring may not be well-accepted by a certain locale when the local government or the people are eager to achieve economic development (Ho 2001; Tang and Zhan 2008). Thus, such ideas cannot be regarded as the societal-recognized moral resources-II, but must remain as ENPO-2's self-chosen moral resource-I.

Even though, Organizer-2 believes that every citizen has the right and responsibility to monitor the environment and that grassroots ENPOs can actually "help" the government in the long term despite disagreeing with the government on certain issues because the ENPOs stand for the public interest rather than small-groups' interests. He explains as follows:

China faces serious environmental and natural resource problems... Yet the officials lack awareness of the importance of environment protection... I have many suggestions about voluntary service and environmental protection... For example, water pollution. According to the current law, only the victims can make accusations. However, in my opinion, anyone who is concerned about the pollution should have the right to prosecute...To enhance public awareness and environmental justice, we also provide free environmentrelated legal consultation for the needy people. (Interview, December 16, 2006) 
Unlike the enterprises that operate for interests, we make suggestions for a wider public interest. Different perspectives or opposite opinions are not for the government. On the contrary, the government should make good use of our role as overseers. We can help monitor pollution and deliver the grassroots message to the government. (July 24, 2012)

Since the organization chooses several different ideals as the organization's self-chosen moral resource-I and societal-recognized moral resources-II, ENPO-2 organizes many different kinds of environmental protection activities, which mainly include helping primary schools carry out environmental education, organizing family activities such as planting trees, cooperation with universities and other institutions to conduct environmental surveys to assess the environmental quality of certain neighborhoods, provide environment-related legal consultations, and other advocacy activities (Interviews, Organizer-2, July 24, 2012; II-Volunteer6, December 19, 2013).

Since Organizer-2 is the only full-time staff member of ENPO-2, all ENPO-2 activities require volunteer support and participation. Fortunately, ENPO-2 has attracted volunteers who choose to participate in different activities. On one hand, thanks to the societal-recognized moral resources-II, although some volunteers don't think an ENPO can effectively monitor the environment, they would like to support ENPO-2's environmental education and other family activities. For instance, the volunteers I\& II-Volunteer7 and II-Volunteer5, who have volunteered for ENPO-2 since it was established, would like to take responsibility for environmental protection, but they won't participate in activities that would risk confronting the government. They further explained by stating the following:

I\& II-Volunteer7: The environment affects every one of us. Environmental protection is a responsibility for every human being... I participate in a lot of environmental protection activities... I hope to improve the well-being of all people.... Yet, an individual, or an ENPO's power is very insignificant. Only the government can promote a fundamental change. (December 31, 2006)

II-Volunteer5: Each citizen should participate in environmental protection activities... I'd like to join some activities organized by ENPO-2, yet, I have a standard in my heart of what I ought to and ought not to do... In my opinion: the government's attention is the most important. The pollution plants are approved by the government, aren't they? (Interview, December 23, 2006)

Alternatively, thanks to strong beliefs in environmental participation, Organizer2 and some of the volunteers initiate many other volunteer-based environmental projects and actions, such as making suggestions to the government, providing environment-related legal consultation for citizens, and other environmental advocacy activities. For instance, II-Volunteer6 joins all kinds of activities. He expressed that, although sometimes ENPO-2's efforts were not successful, he still 
expects their grassroots activities can get the support from the government, and he believes that their monitoring actions can positively impact environmental protection in the long term. He gave an example for their monitoring activity and explained his idea as follows:

Driven by interests, the Park, BTQ, someone proposed to build a tea-bar near the North Door of the Park, located inside the Park... The (EIA), which is required prior to construction, was passed by the Environmental Protection Department of City J, who started building the tea-bar. We thought the construction would negatively affect the environment. We visited the construction site and published our viewpoints in the newspaper. Moreover, we asked the Environmental Association and the School of Environment of University $S$ to conduct the EIA again. University S is the top University in Province $S$ and is one of the best universities in China. We thought that University $S$ would have standard techniques for the EIA and that the Environmental Protection Department should accept the EIA report of University S. We appealed to stop the construction and invited the journalists to go with us to the Environmental Protection Department of City $J$ and Environmental Protection Department of Province S... However, we failed, despite the fact that Province S's EIA report supports our arguments... Although we cannot stop the construction, we have done everything we can. Even so, I expect that the government can give more support to us. And I hope a better understanding could be built between the government and us. (Interview, December 20, 2006)

We are endeavoring to lead the way towards promoting environmental protection. We cannot affect everybody by organizing one activity. Yet, if there will be increasingly more environmental protection activities, they will gradually affect people and the government... (Interview, February 13, 2007)

\section{Challenges for Future Development of ENPOS}

\subsection{Major Challenges for ENPO-1: Ineffective Management and Lacking of Transparency}

Though the ascribed political capital-I guarantees the government's support and helps ENPO-1 obtain donations from corporations, evidence shows several management problems, such as ineffective management and lacking transparency, which may discourage public participation. For example, I\&IIVolunteer7, who has often served in both ENPO-1 and ENPO-2, opined that ENPO-1 won't be successful in the long run since it was too dependent on the government. He described ENPO-1's problematic management of the treeplanting activity, and expressed that he would not donate to ENPO-1 in the future as follows: 
They (i.e. ENPO-1) planted trees, yet not took care of the trees. About $80 \%$ of the trees were dead.... ENPO-2's activities are much better than ENPO-1. Before planting the trees, ENPO-2 will choose the right place for planting, and take good care of the trees after the trees are planted (December 31, 2006).... I think that ENPO-1 depends on the government too much. The enterprise would like to donate to ENPO-1 is because its president is the retired governor... I seldom participate in the activities organized by them now. And I would not donate to them again since their management is poor. I don't think ENPO-1 could be successful in the future if it only relies on the government. (February 10, 2007)

Actually, in 2006, the administrator, Organizer-1, realized that the management of ENPO-1 was unsatisfied and admitted that it needs to improve in many areas. Organizer-1 stated the following:

Our funding mainly comes from corporate donations, and we have some other incomes... but we are at the stage of just starting, and the operation of the Fund is unprofessional and sometimes not properly handled... I think there are many things we still need to improve. For example, we have many volunteers, including students, elderly people, and pupils. They are enthusiastic, yet our management are not well enough.... (December 18, 2006)

However, many years passed and there is still a lot of room for ENPO-1 to improve. ${ }^{4}$ For example, according to the China Foundation Transparency Index (FTI), ENPO-1 is ranked 21 among the 77 foundations in Province-S, and its total score is less than 50 (China Foundation Center 2015). As FTI (2015) also reports ENPO-1's net assets, the donation income and expenditures between 2011 and 2013, we found that is very confusing that the organization's expenditure is zero in 2011 while its net assets are 2.93 million and the donation income is 0.7 million.

\subsection{Major Challenges for ENPO-2: The Difficult Guanxi with Its Professional Management Unit and Financial Unsustainability}

It has been found that most grassroots ENPOs receive little financial support from the government and only those well-connected to the government are likely to get some funding from the professional management unit (He 2006; Xu 2012).

4 We have tried to contact ENPO-1 for follow-up interviews to understand the organization's recent development. However, the previous administrator, Organizer-1, has left the organization and the current staff refused our request, stating, "If you really wish to study us, you should ask help from the related governmental departments, such as the Environmental Protection Bureau, to introduce you to us" (July 23, 2012). Though the staff didn't provide any details, the suggestion of seeking other governmental departments' approval disclosed that the organization's bureaucratic management mode is relatively inflexible. 
The finding of this study is consistent with previous studies. As ENPO-2 has a very difficult guanxi with the professional management unit (i.e., the Environmental Protection Bureau of City J), the organization not only never received any public funds, but they also cannot receive membership fees, which are allowed by the Regulations on the Registration and Administration of Social Organizations. Organizer-2 explains as follows:

As you know, when ENPO-2 was set up, I offended the leaders of the Environmental Protection Bureau of City J: They did not want to supervise us as our professional management unit. I am stubborn. I requested help from deputies of the People's Congress. They reluctantly agreed to be our professional management unit. Thus we can be registered as a social organization...

However, we cannot operate as a social organization, which can recruit members, collect membership dues, or receive donations. Without the City J Finance Bureau's permit, we cannot issue formal receipts, which can prove the members or donors give money for a social organization and can enjoy the tax reduction. It is because, according to the rules, to apply for the "permit", any social organization needs to provide its professional management unit's BANK CODE NUMBER to the Finance Bureau. After reluctantly agreeing to be our professional management unit, the Environmental Protection Bureau refused to give us its BANK CODE NUMBER. Therefore, we cannot get the "permit" for receiving money...

Situations have always been like this... The relationship with the professional management unit is very difficult, unhealthy... But we can do nothing about it. (July 24, 2012)

Clearly, because ENPO-2 cannot receive membership dues and donations, the organization's financial state is fragile. Though sometimes volunteers donate certain goods (e.g., seeds, young trees, etc.), ENPO-2 does not have any funding source and Organizer-2 has to use his savings to operate the organization. I\& IIVolunteer7 describe the situation as follows:

I know that Organizer-2 used his own money to organize environmental activities. I am satisfied with ENPO-2’s financial transparency. In the spring, I spent about ¥RMB1, 000 to buy young trees and donate them to ENPO-2. ENPO-2 invited citizens and families to plant the young trees. I do not need a receipt. I am proud that I helped the streets become green. (Februry10, 2007)

Although ENPO-2 has received some support from volunteers, Organizer-2 worries about ENPO-2's sustainable development. Because without the professional management unit's support, ENPO-2 can neither raise money from the public nor get funding from the government. Organizer-2 explains as follows:

I always use my personal savings to operate ENPO-2. We are reviewed annually. The annual review not only requires that each social organization has lawful assets and a source of funds, but also requires that each organization has a fund of no less than $¥ R M B 30,000$ for operation. It requires a lot of money to operate a social organization. I worry that ENPO-2 won't exist when the money runs out... (July 24, 2012) 


\section{Discussion and Implications for Policy}

This study combines the moral resources and political capital perspective with the theoretical arguments of guanxi and resource dependence theory to examine two typical ENPOs): the government-organized ENPO-1 and the grassroots ENPO-2. The findings are summarized in Table 2.

Table 2: A comparison of the two ENPOs: ENPO-1 and ENPO-2.

\begin{tabular}{|c|c|c|}
\hline & $\begin{array}{l}\text { Government-organized } \\
\text { ENPO-1 }\end{array}$ & Grassroots ENPO-2 \\
\hline Year established & 2001 & 2002 \\
\hline Professional management unit & $\begin{array}{l}\text { Environmental Protection } \\
\text { Agency of Province } S\end{array}$ & $\begin{array}{l}\text { Environmental Protection } \\
\text { Agency of City J }\end{array}$ \\
\hline Approved by and registered with & $\begin{array}{l}\text { Civil Affairs Department of } \\
\text { Province } S\end{array}$ & $\begin{array}{l}\text { Civil Affairs Department of } \\
\text { City J }\end{array}$ \\
\hline Registration level & Provincial & Municipal \\
\hline Main funding resources & $\begin{array}{l}\text { Governmental funding and } \\
\text { donations }\end{array}$ & $\begin{array}{l}\text { Private donations from } \\
\text { members }\end{array}$ \\
\hline Full-time staff & Less than 20 people & One person (i.e., Organizer 2) \\
\hline Ascribed Political Capital-I & Yes & No \\
\hline Achieved Political Capital-II & Yes & No \\
\hline Self-Chosen Moral Resource-I & $\begin{array}{l}\text { To improve environmental } \\
\text { protection and assist with } \\
\text { implementing the CCP's } \\
\text { spirit }\end{array}$ & $\begin{array}{l}\text { To improve public } \\
\text { participation in } \\
\text { environmental monitoring }\end{array}$ \\
\hline $\begin{array}{l}\text { Societally Recognized Moral } \\
\text { Resource-II }\end{array}$ & $\begin{array}{l}\text { To improve environmental } \\
\text { protection and assist with } \\
\text { implementing the CCP's } \\
\text { spirit }\end{array}$ & $\begin{array}{l}\text { The ideal of environmental } \\
\text { protection }\end{array}$ \\
\hline $\begin{array}{l}\text { Relationships (or guanxi) with } \\
\text { governments }\end{array}$ & $\begin{array}{l}\text { Very good relationships with } \\
\text { various governmental } \\
\text { departments }\end{array}$ & $\begin{array}{l}\text { A relatively good } \\
\text { relationship with the } \\
\text { Department of Civil Affairs, } \\
\text { yet a strained relationship } \\
\text { with its professional } \\
\text { management unit (i.e., the } \\
\text { Environmental Protection } \\
\text { Department) }\end{array}$ \\
\hline
\end{tabular}


Table 2: (continued)

\begin{tabular}{|c|c|c|}
\hline & $\begin{array}{l}\text { Government-organized } \\
\text { ENPO-1 }\end{array}$ & Grassroots ENPO-2 \\
\hline Chief activities or services & $\begin{array}{l}\text { Environmental propaganda } \\
\text { and environmental education }\end{array}$ & $\begin{array}{l}\text { Environmental education, } \\
\text { family-oriented activities, } \\
\text { environmental surveys, } \\
\text { environment-related legal } \\
\text { consultations, and other } \\
\text { activities of advocacy }\end{array}$ \\
\hline Major obstacles & $\begin{array}{l}\text { Ineffective management and } \\
\text { lack of transparency }\end{array}$ & $\begin{array}{l}\text { A difficult relationship with } \\
\text { its professional } \\
\text { management unit and its } \\
\text { precarious financial } \\
\text { situation }\end{array}$ \\
\hline
\end{tabular}

First, in the context of gradual reform in socialist China, good guanxi with a certain government body cannot necessarily warrant NPOs resources, yet ascribed political capital-I cannot only ensure good guanxi with government departments but also may enhance the NPOs' opportunities to obtain more resources. In this study, for example, ENPO-1 has not only gained advantages by way of ascribed political capital-I, but also nurtured strong relationships with government departments, public schools, and mass media. As a result, ENPO-1 operates smoothly with plenty of resources since most institutions seek to cooperate with and donate to the organization. By contrast, though ENPO-2 has developed relatively good guanxi with the Department of Civil Affairs, this kind of guanxi can neither improve its strained guanxi with its professional management unit (i.e., the Environmental Protection Department) nor help the organization to obtain resources from the government.

Second, the case of government-organized ENPO-1 reveals that, if this kind of NPO's leaders have government experience, then these NPOs are more likely to work closely with the CCP and acquire various resources from the government. In this regard, the political status of these NPOs' leaders can also be regarded to constitute a kind of ascribed political capital-I, because their status can enhance the organizations' access to the current political system. However, since most people in charge of ENPO-1 have similar government experience, current and potential volunteers, as well as the public, may feel dissatisfied with these organizations' management and even regard leaders of government-organized ENPOs to be using their organizations to pursue power for themselves (Keane 1991; Fyfe 2005). In the long run, this perception will 
discourage volunteers from contributing their time and donators from contributing money to these organizations' development. Therefore, since this kind of organization's decision-making is independent, its transparency needs to be improved.

Third, though the grassroots ENPO-2 has little ascribed political capital-I, it possesses advantages in terms of self-chosen moral resource-I, which can help to unite organizational members as a cohesive team and unify their activity (Xu and Ngai 2011). In this regard, self-chosen moral resource-I can help grassroots ENPOs to be relatively independent of the government and take responsibility for monitoring the environment. However, in ENPO-2's case, its self-chosen moral resource-I (e.g., advancing environmental monitoring) is relatively independent of the principles of its professional management unit (i.e., the Environmental Protection Department), which greatly values social harmony and functional efficiency. In other words, though ENPO-2's efforts in promoting public participation in environmental monitoring may contribute to environmental protection, the Environmental Protection Department has not supported public participation because such may increase the department's workload and thus reduce its efficiency. As a result, its difficult relationship with its professional management unit has partly prevented ENPO-2 from obtaining resources and support from the Chinese government.

Fourth, as $\mathrm{Xu}$ and Ngai (2011) have posited, societally recognized moral resource-II can help grassroots NPOs to achieve political capital-II because moral resource-II can enhance the government's trust in grassroots NPOs. However, the findings of this research do not support this previous finding. Although ENPOs have generally taken advantage of having societally recognized moral resource-II, for both the Chinese central government and the public have recognized the importance of environmental protection ( $\mathrm{Ru}$ and Ortolano 2009; $\mathrm{Xu}$ and Ngai 2011), this study reveals that societally recognized moral resource-II cannot necessarily help the ENPO to achieve political capital-II, largely because the certain governmental department's interest may conflict with societal interests. For example, and as discussed above, though societally recognized moral resource-II is likely to help the grassroots ENPO-2 to receive donations and help from volunteers, ENPO-2 can neither cultivate good guanxi with its professional management unit nor achieve political capital-II by way of their environmental monitoring actions.

In short, this study's findings not only reveal that both the governmentorganized ENPO-1 and grassroots ENPO-2 have unique strengths and weaknesses in obtaining government funding, but also demonstrate that ascribed political capital-I is a more influential factor for resource allocation than guanxi and moral resources. Given that the Chinese government has played a dominant 
role in legalization and governance arrangements for ENPOs, four policy implications for improving the future development of ENPOs in China emerge from the findings.

First, to reduce conflicts among environmental protection, local governments' short-term interests, the use of national natural resources, and sustainable development, the central government of China could introduce multiple indexes to evaluate local governments. In addition to traditional evaluation factors, including GDP and carbon emissions, the multiple index for evaluation should include average life expectancies and the morbidity of environmentrelated diseases in a certain administrative area. In this way, local governments can share extensive common interests with grassroots ENPOs that wish to improve public participation in environmental monitoring.

Second, the central government could invite grassroots ENPOs to rate putatively relevant local governments (e.g., their professional management unit and/ or the Department of Civil Affairs). Since it is not feasible for the government to supervise itself or be monitored by GONGOs, which work closely with the government, allowing relatively independent grassroots ENPOs to evaluate respective government departments could decrease the possibility of the government's regarding ENPOs as an extra burden to their workload. Furthermore, such a strategy would improve the effective functioning of the government in environmental protection.

Third, standard guidelines that ensure that government-organized and grassroots ENPOs enjoy equal opportunities in applying for funds are necessary. This fair-play regulation will not only help grassroots ENPOs, which have little political capital, to obtain funding, but also benefit government-organized ENPOs, which have had stable funding sources. In other words, fair competition could push both government-organized and grassroots organizations to improve their capacities in terms of program management, transparency, and service quality, among other aspects.

Last but not least, the requirements and procedures for NPOs' registration should be simplified. Actually, Shenzhen Municipal Government in July 2009, Beijing Municipal Government in August 2011, and Guangdong Provincial Government in November 2011 all relaxed the registration qualifications for NPOs (China Youth Daily 2012). Such institutional renovation is worth being applied at the national level. For one, as more NPOs are established, a greater variety of services can be provided. Furthermore, unlike current regulations that allow only one NPO per type to be registered in an administrative area, deregulated policy measures effectively introduced competition among NPOs - including both government-organized and grassroots ENPOs - and stand to thereby improve the quality of their services. 


\section{Conclusions}

In this article, we have combined perspectives on moral resources and political capital with the theoretical arguments of guanxi and resource dependence to explore the strengths and weaknesses of Chinese government-organized and grassroots ENPOs in environmental protection. By comparing the governmentorganized ENPO-1 and grassroots ENPO-2, the findings extend research on Chinese ENPOs in three dimensions. First, though scholars during the past two decades have investigated either Chinese government-organized ENPOs (Wu 2002, 2003) or grassroots ENPOs (Ho 2001; Tang and Zhan 2008; Ru and Ortolano 2009), this study marks the first attempt to empirically develop a systemic understanding of the strengths and weaknesses of an environmental GONGO and grassroots ENPO in China. Second, this study theoretically not only reveals complementary relationships among moral resources, political capital, and guanxi, but also illustrates how these factors affect resource allocation by examining the chief activities and services, challenges, and funding resources of the governmentorganized ENPO-1 and grassroots ENPO-2. Third, and somewhat more practically, this article also highlights implications for policy toward improving both government-organized and grassroots ENPOs' future performance.

Several limitations of this study should be noted. First, though we believe that the implications for policy based on our empirical findings can enlighten policymakers toward facilitating institutional innovations, the government is not expected to accept such recommendations in the short term since the Chinese government has adopted an approach of gradual reform that emphasizes stability (McMahon and Zou 2011). Even though, there are reasons to justify the Chinese government's future consideration of these implications for policy toward promoting the development of ENPOs as well as environmental protection in China. Since the Chinese public has increasingly recognized environmental problems, evidence shows that the central government has made credible commitments to improve transparency in the area of environmental protection. The Regulation of the People's Republic of China on the Disclosure of Government Information (State Council 2007) and Measures for the Disclosure of Environmental Information (State Environmental Protection Administration 2007) have been promulgated to promote public participation in environmental monitoring. This reveals that the government would realize that both governmentorganized and grassroots ENPOs share similar moral resources-II in terms of environmental protection, and there is much to gain if both kinds of ENPO are treated equally in the realm of environmental protection, which can benefit both China and the world in the long run. 
Second, although we have carefully selected two ENPOs that were comparable in terms of location, activities, and time of establishment, our sample of only two cases is small. Due to the Chinese government's current regulation allowing only one organization of each type in a given area, however, it is difficult to find multiple ENPOs that are comparable in the same area of China, unless in capital cities (e.g. City J) where similar NPOs can be registered at different levels (e.g., ENPO-1 was registered at the provincial level and ENPO-2 at the municipal level). Given that China is an immense country with diverse local cultures and since the nature of guanxi can differ on a case-by-case basis, in the future we hope to extend our research to different cities as a means to further our understanding of the development of ENPOs and refine perspectives on guanxi, resource dependence theory, moral resources, and political capital in the Chinese context. Altogether, with this first attempt to develop a systematic understanding of the strengths and weaknesses of environmental GONGOs and grassroots ENPOs in promoting environmental protection in China, we hope that this paper can serve as a good starting point for soliciting the valued opinions of others.

\section{References}

Adorno, T. 2000. Problems of Moral Philosophy. Edited by Thomas Schroder; translated by Rodney Livingstone. Stanford, CA: Stanford University Press.

Baum, J. A., and J. E. Dutton. 1996. "The Embeddedness of Strategy." In Advances in Strategic Management, edited by P. Shrivastave, A. Huff, J. E. Dutton and H. B. Thorelli. Vol. 13, 1-15. Greenwich, CT: JAI.

Bian, Y., and S. Ang. 1997. "Guanxi Networks and Job Mobility in China and Singapore." Social Forces 75 (3):981-1005.

Bourdieu, P. 1998. Practical Reason: On the Theory of Action. Cambridge: Polity Press.

Cai, Y. 2010. Collective Resistance in China: Why Popular Protests Succeed or Fail. Stanford, CA: Stanford University Press.

Chandler, W., and Y. Wang. 2009. Memo to Copenhagen: Commentary Is Misinformed - China's Commitment Is Significant. Washington, DC: Carnegie Endowment for International Peace.

Chen, W. 2007. "Does the Colour of the Cat Matter? The Red Hat Strategy in China's Private Enterprises." Management and Organization Review 3 (1):55-80.

Chen, C. C., X. Chen, and S. Huang. 2013. "Chinese Guanxi: An Integrative Review and New Directions for Future Research.” Management and Organization Review 9 (1):167-207.

China Digital Times. 2013. In Beijing, Fog or Smog? Accessed October 14, 2015. http://chinadigitaltimes.net/2011/12/in-beijing-fog-or-smog/

China Environmental Culture Promotion Association. 2008. Summary of "The Chinese Public Environmental Index (2008)". Accessed April 17, 2012. http://www.tt65.net/zhuanti/ zhishu/2008gongzhongzhishu/zishuzongshu2008.pdf 
China Foundation Center. 2015. China Foundation Transparency Index. Accessed May 3, 2015. http://ftien.foundationcenter.org.cn/

China Institute of City Competitiveness. 2011. Chinese City Competitiveness Rankings (2008-2011) (Zhongguo chengshi jingzhengli paihangbang bangdan, in Chinese). Accessed March 17, 2012. http://www.china-citynet.com/yjh/fyphb.asp

China Youth Daily. 2012. Will the Spring Come to the Grassroots Organizations? The Grassroots “Gongyi” Organizations Need Properly Defined (Minjian zuzhi nengfou yinglai zhengce nuanchun Minjian gongyi zuzhi youdai zhengming) (in Chinese). Accessed June 18, 2012. http://www.wenming.cn/wmpl_pd/shzt/201202/t20120209_493545.shtml

Cigler, B. A. 1999. "Pre-Conditions for the Emergence of Multicommunity Collaborative Organizations." Policy Studies Review 16 (1):87-102.

Cooper, C. M. 2006. "'This Is Our Way In': The Civil Society of Environmental NGOs in South-West China." Government and Opposition 41 (1):109-36.

Eikenberry, A., and J. Klover. 2004. "The Marketization of the Nonprofit Sector: Civil Society at Risk?.” Public Administration Review 64 (2):132-40.

Fei, X., G. G. Hamilton, and Z. Wang. 1992. From the Soil, the Foundations of Chinese Society: A Translation of Fei Xiaotong's Xiangtu Zhongguo, with an Introduction and Epilogue. Berkeley, CA: University of California Press.

Froelich, K. A. 1999. "Diversification of Revenue Strategies: Evolving Resource Dependence in Nonprofit Organizations." Nonprofit and Voluntary Sector Quarterly 28 (3):246-68.

Fyfe, N. R. 2005. “Making Space for 'Neo-Communitarianism'? The Third Sector, State and Civil Society in the UK." Antipode 37 (3):536-57.

Galaskiewicz, J. 1985. "Interorganizational Relations.” Annual Review of Sociology 11:281-304.

Gao, C., and M. Acar. 2005. "Understanding Collaboration Among Nonprofit Organizations: Combining Resource Dependency, Institutional, and Network Perspectives." Nonprofit and Voluntary Sector Quarterly 34 (3):340-61.

Gilley, B. 2012. "Authoritarian Environmentalism and China's Response to Climate Change." Environmental Politics 21 (2):287-307.

He, Z. 2006. "The Analysis of the Institutional Obstacles of the Development of Civil Society Organizations in China (in Chinese)." Journal of the Party School of CPC Ningbo Municipal Committee (6):23-30.

Ho, P. 2001. "Green Without Conflict? Environmentalism, NGOs, and Civil Society in China." Development \& Change 32 (5):893-921.

Kant, I. 1998. Critique of Pure Reason. Translated by J.M.D. Meiklejohn. Raleigh, NC; Alex Catalogue; Boulder, CO: NetLibrary.

Keane, J. 1991. The Media and Democracy. Cambridge: Polity Press.

Lang, G., and Y. Xu. 2013. "Anti-Incinerator Campaigns and the Evolution of Protest Politics in China." Environmental Politics 22 (5):832-48.

Lin, Y. 2004. "Personality of People of City J and Its Influence." Journal of Shandong Administrative College and Shandong Economic Management Personnel College 60:124-6.

Lu, Y. 2007. "Environmental Civil Society and Governance in China." International Journal of Environmental Studies 64 (1):59-69.

Lu, Y. 2009. Non-Governmental Organisations in China: The Rise of Dependent Autonomy. New York: Routledge.

Lynd, R. S., and H. M. Lynd. 1929. Middletown: A Study in Contemporary American Culture. New York: Harcourt, Brace and Company. 
Ma, Q. 2002. "The Governance of NGOs in China Since 1978: How Much Autonomy?." Nonprofit and Voluntary Sector Quarterly 31 (3):305-28.

Macedo, I. M., and J. C. Pinho. 2006. "The Relationship Between Resource Dependence and Market Orientation: The Specific Case of Non-Profit Organizations." European Journal of Marketing 40 (56):533-53.

Ma, X., and L. Ortolano. 2000. Environmental regulation in China institutions, enforcement, and compliance. Boulder, CO: Rowman, Littlefield.

McMahon, P. C., and Y. Zou. 2011. "Thirty Years of Reform and Opening up: Teaching International Relations in China." PS: Political Science \& Politics 44 (1):115-21.

Ministry of Civil Affairs. 2002. Reply about questions related to social organizations to set up economic entities (in Chinese). Accessed October 14, 2015. http://www.sdpef.cn/Article/ regulation/200909/38.shtml

Ni, P.F. 2006. Annual Report on Urban Competitiveness. No. 4 (Zhongguo Chengshi Jinzhengli Baogao, No.4) (in Chinese). Beijing: Social Sciences Academic Electronic \& Audiovisual Press.

Oliver, C. 1990. "Determinants of Interorganizational Relationships: Integration and Future Directions." Academy of Management Review 15 (2):241-65.

Pacific Environment. 2009. The State of China's Environment. Accessed November 10, 2009. http://www.pacificenvironment.org/article.php?list=type\&type=104

People. 2008. Strengths of NGOs Should Not Be Neglected (NGO liliang buke hushi) (in Chinese). Accessed October 8, 2009. http://www.022net.com/2008/11-19/ 521958293216324.html

Pfeffer, J., and G. R. Salancik. 1978. The External Control of Organizations: A Resource Dependence Perspective. New York: Harper and Row.

Qi, H. 2004. "The Freedom of Association and the System of Non-Corporate Associations (in Chinese)." Global Law Review (3):295-303.

Qu, Q. 2011. "Evaluation of the Third Plenary Session of the Communist Party of China." Journal of Chinese Communist Party History Studies 4:5-13.

$\mathrm{Ru}$, J., and L. Ortolano. 2009. "Development of Citizen-Organized Environmental NGOs in China." Voluntas 20:141-68.

State Administration of Taxation. 1999. Regulations on the Collection and Management of the Corporate Income Tax of Public Institutions, Social Groups and Private Non-Corporate Units. Accessed October 14, 2015. http://www.chinatax.gov.cn/2013/n2925/n2956/ c310091/content.html

State Council. 1998a. Regulations on the Registration and Administration of Social Organizations. Accessed May 12, 2012. http://www.people.com.cn/item/flfgk/gwyfg/ 1998/112103199803.html

State Council. 1998b. Regulations on the Registration and Administration of Private Nonenterprise Units. Accessed May 12, 2012. http://www.mca.gov.cn/article/zwgk/fvfg/ mjzzgl/200709/20070900001726.shtml

State Council. 2004. Regulations on the Registration and Administration of Foundations. Accessed May 12, 2012. http://big5.gov.cn/gate/big5/www.gov.cn/xxgk/pub/govpublic/ $\mathrm{mrlm} / 200803 / \mathrm{t20080328 \_ 31616.html}$

State Council. 2007. Regulation of the People's Republic of China on the Disclosure of Government Information. Accessed May 12, 2015. http://www.gov.cn/zwgk/2007-04/24/ content_592937.htm 
State Environmental Protection Administration. 2007. Measures for the Disclosure of Environmental Information. Accessed May 12, 2015. http://www.mep.gov.cn/info/gw/jul ing/200704/t20070420_102967.htm

Statistical Information Net of City J. 2015. The Main Data of the Sixth National Population census in 2010 of City J. Accessed April 29, 2015. http://tongji.oversea.cnki.net/npccen/EngNavi/ NaviDefault.aspx

Tang, S., and X. Zhan. 2008. "Civic Environmental NGOs, Civil Society, and Democratisation in China." The Journal of Development Studies 44 (3):425-48.

The Economist. 2009. "Asia: Open Constitution Closed; China, the Law and NGOs," July 25, 2009, 392 (8641): 38.

The gate-way website of the City J People Government. 2006. Regulations on Voluntary Service in City $J$.

Tian, K. 2004. “Organizational Operation Under Non-Coordinate Constraint: A Framework of Research on the Relationship Between the Charity Organizations and the Government in China (in Chinese)." Sociological Research 2004 (4):64-75.

Wang, M., and X. J. Jia. 2003. "Problems about Legislation for China's NGOs (in Chinese)." Journal of Tsinghua University (Philosophy and Social Sciences) 18 (S1):100-6.

Wu, F. 2002. "New Partners or Old Brothers? GONGOs in Transnational Environmental Advocacy in China." China Environment Series 5:45-58.

Wu, F. 2003. "Environmental GONGO Autonomy: Unintended Consequences of State Strategies in China." The Good Society 12 (1):35-45.

Xinhuanet. 2002. Full Text of Jiang Zemin's Report at 16th Party Congress. Accessed May 2, 2015. http://news.xinhuanet.com/ziliao/2002-11/17/content_693542.htm

Xu, Y. 2012a. "Non-Governmental Organizations in China: Development and Challenges." In China: Development and Governance, edited by Wang Gungwu and Zheng Yongnian. Singapore: World Scientific.

Xu, Y. 2012b. "Chinese Communist Youth League, Political Capital, and the Legitimizing of Volunteering in China." International Journal of Adolescence and Youth 17 (2-3):95-112.

Xu, Y. 2013. "Moral Resources, Political Capital and the Development of Social Work in China:

A Case Study of City J in Shandong Province." British Journal of Social Work 43 (8):1589-610.

Xu, Y., and N. P. Ngai. 2011. "Moral Resources and Political Capital: Theorizing the Relationship Between Voluntary Service Organisations and the Development of Civil Society in China." Nonprofit and Voluntary Sector Quarterly 40 (2):247-69.

$\mathrm{Xu}, \mathrm{Y}$. forthcoming. "Volunteerism and the State: A Case Study of China." In Perspectives on Volunteering: Voices from the South, edited by Jacqueline Butcher and Christopher J. Einolf. New York: Springer.

Yang, G. 2005. "Environmental NGOs and Institutional Dynamics in China." The China Quarterly 181:46-66.

Young, D. R. 1998. "Commercialism in Nonprofit Social Service Associations: Its Character, Significance, and Rationale." Journal of Public Analysis and Management 17 (2):278-97.

Young, D. R., N. Bania, and D. Bailey. 1996. "Structure and Accountability: A Study of National Nonprofit Associations." Nonprofit Management and Leadership 6:347-65.

Zhao, B. 2005. "On the Charity Cause of City J in Modern China (1904-1937)." Journal of Jinan University 15 (1):62-6. 